\title{
Bromatological Composition of Moringa of Sumbe (C. Sul) and Cubal (Benguela)
}

\author{
Armindo Paixão ${ }^{1, *}$, Isabel Panzo ${ }^{2}$, Raimundo Kwaia ${ }^{3}$, Luzidia Filemone ${ }^{4}$, Diassonama L. Maria ${ }^{1}$, \\ Edna-Marisa de Oliveira $^{1}$, Esmeralda Inácio ${ }^{1}$, Ataulfo Pereira ${ }^{5}$, Joaquim Morais ${ }^{1}$, Cristóvão Simões ${ }^{1}$ \\ ${ }^{1}$ Departament of Animal Health and Food Technology, Faculty of Veterinary, José Eduardo dos Santos University, Huambo, An- \\ gola. \\ ${ }^{2}$ Departament of Animal production, Cubal Agricultural Technical School, Benguela, Angola. \\ ${ }^{3}$ Departament of Animal Prodution, Higher Polytechnic Institute of Cuanza-Sul, Angola. \\ ${ }^{4}$ Departament of Social Sciences, Faculty of Human Sciences, Social and Cultural, Agostinho Neto University, Luanda, Angola. \\ ${ }^{5}$ Departament of Food Security, Cuito Cuanavale University, Cuando Cubango, Angola.
}

\begin{abstract}
How to cite this paper: Armindo Paixão, Isabel Panzo, Raimundo Kwaia, Luzidia Filemone, Diassonama L. Maria, Edna-Marisa de Oliveira, Esmeralda Inácio, Ataulfo Pereira, Joaquim Morais, Cristóvão Simões. (2022) Bromatological Composition of Moringa of Sumbe (C. Sul) and Cubal (Benguela). Internationa Journal of Food Science and Agriculture, 6(1), 60-63.

DOI: $10.26855 /$ ijfsa.2022.03.008
\end{abstract}

Received: December 25, 2021

Accepted: January 23, 2022

Published: February 21, 2022

*Corresponding author: Armindo Paixão, Departament of Animal Health and Food Technology, Faculty of Veterinary, José Eduardo dos Santos University, Huambo, Angola.

Email: armindo7000@hotmail.com

\begin{abstract}
With the aim of determining some bromatological parameters of moringa from two different locations and at the same period of the year, fresh leaves were collected and air-dried, and then ground to be converted into powder. This was passed through a sieve, packaged and sent to the Central Laboratory for Food and Agriculture in Luanda in order to determine the content of crude protein, crude fibre, ether extract and vitamin C. The evaluation of dry matter, moisture, ashes and carbohydrates was carried out at the Centre for Research and Agro-Food Technology of the Faculty of Veterinary. Both samples showed promising and varied bromatological contents, having the moringa from Cubal presented the following values: crude protein $-22.33 \%$, crude fibre $-0.14 \%$, ether extract- $10.54 \%$ and carbohydrate $47.43 \%$, while in the moringa from Sumbe the crude protein was $24.72 \%$, crude fibre $0.24 \%$, ether extract $5 \%$ and carbohydrate $52.65 \%$.
\end{abstract}

\section{Keywords}

Moringa, Sumbe and Cubal, bromatology

\section{Introduction}

Moringa is considered a sustainable, economically viable, robust and healthy nutrient-rich food supplement, particularly for those suffering from malnutrition, especially in developing countries. Besides, it has been used as an alternative to improve food and nutrition security status [1].

Moringa oleifera Lam. is a long-life cycle tree from the family of Moringaceae, native to northern India, still considered an underused plant. All parts of the plant have shown a remarkable range of certain functional properties, which make it a biomaterial for food use [2]. Due to its richness in nutritional and bioactive components, it plays an important role from a nutritional and therapeutic point of view [3]. The same authors [4] also state that the component of moringa leaves vary depending on their geographical location. With respect to human and animal nutrition, moringa leaves contain high protein content, are rich in essential amino acids, minerals, vitamins and antioxidant substances, being deemed a highly nutritious functional food [5]. Due to the properties demonstrated by the plant, the dehydrated leaves of moringa are increasingly gaining prominence as a fortifier, which leads it to be part in processed foods [6]. Studies by several authors related to the therapeutic properties of moringa presented it as having analgesic and anti-inflammatory properties [7], antioxidant effect [8], combating obesity [9], in addition to controlling blood glycemia (anti-diabetes) 
[10].

This study was aimed at determining some bromatological parameters of moringa from the regions of Sumbe and Cubal in the provinces of Cuanza Sul and Benguela, respectively, for use in human food and animal feed.

\section{Material and Methods}

The work was developed from June 2019 to February 2020, part of which was carried out in the field with the harvesting of the leaves of the plant in the two locations, and the other in laboratories for determining the bromatological parameters.

\subsection{Harvesting and drying sites}

The fresh moringa leaves were harvested in March in the Municipality of Sumbe, district E15, at latitude $11^{\circ} 11^{\prime} 34.54^{\prime} \mathrm{S}$ and longitude $13^{\circ} 51^{\prime} 10.93^{\prime} \mathrm{E}$ in the province of Kwanza Sul, while in Benguela that was carried out in October in the Municipality of Cubal, at the Escola Técnica Agrária, located at latitude $13^{\circ} 3^{\prime} 41.63^{\prime S}$ and longitude $14^{\circ} 13^{\prime} 39.35^{\prime} \mathrm{E}$. The leaves collected in these two locations were transported to Huambo, to the Centro de Pesquisa Tecnológica de Alimentos [Food Technological Research Centre] (CEPTA) where they were air-dried in the shade according to the techniques described by Cunha [11] and Zatta [12]. The drying lasted five days, after which the leaves were pulverized, sieved and packed in polyethylene bags and kept refrigerated for later use. The transformation of the leaves into powder was done in the traditional mortar and passed through a $200 \mu \mathrm{m}$ sieve. $150 \mathrm{~g}$ of each sample were sent to the Central Laboratory for Food and Agriculture of the Ministry of Agriculture in Luanda.

\subsection{Determination of the bromatological parameters}

The crude protein content was determined according to the Kjeldahl method, using the DK6 Kjeldahl Digestion Analytical Instruments-VELP Scientific, from Italy, while the crude fibre was determined by means of the Weende method, which consists of the acid and alkaline digestion of the sample, whose residue constitutes the crude fibre which is washed with hot water and alcohol, kiln dried, weighed and burnt in a muffle furnace for the elimination of interfering substances of the fixed mineral residue [13]. The fat determination was based on the Soxhlet method, which consists in obtaining free fat by direct extraction with light petroleum, diethyl ether or other type of solvent, using Soxhlet SER 148 equipment from Analytical Instruments, VELP Scientific, from Italy. The ash content of the samples was determined by gravimetric method using incineration muffle equipment of the series F3048C-60, DA Thermo Scientific, VELP, Italian. For the percentage calculation of the ash content the following equation was used:

Furthermore, moisture and dry matters were determined by gravimetric method, and the carbohydrate content was obtained by difference using the following arithmetic formula:

$$
\mathrm{ENN}=100-(\mathrm{PB}+\mathrm{FB}+\mathrm{EE}+\mathrm{MM}+\mathrm{H})
$$

As for the Vitamin C, this was determined by using the gravimetric method, and all analyses were done in triplicate.

\section{Result and Discussion}

The analysis of bromatological parameters of moringa showed promising contents of crude protein, fats, ash and moisture in both samples, as shown in Table 1 .

Table 1. Bromatological parameters (dry matter) in percentages

\begin{tabular}{lccccccccc}
\hline \multicolumn{10}{c}{ Parameters\% } \\
\hline & Cude protein & Crude fibre & Ether extract & Ash & Carbohydrate & Moisture & Dry matter & Vitamine C \\
\hline Moringa Sumbe & 24.72 & 0.24 & 5 & 11.54 & 52.65 & 6 & 94 & 0 \\
Moringa Cubal & 22.33 & 0.14 & 10.54 & 13 & 47.43 & 5.9 & 94 & 0.22 \\
\hline
\end{tabular}

The protein content of the moringa harvested in Sumbe was $24.72 \%$, while in Cubal it was $22.33 \%$. This variability may be due to geographical location, harvest period, among other reasons, as one of the factors that cause the chemical composition of a plant to vary is its location. Studies by Almeida et al. [14] and Marinelli [15] have both obtained 24.14\% protein content, values that are similar to those found in this study. Moringa leaves are the most studied and analysed part of the plant. The presence of essential amino acids in M. oleifera leaves and the result of its digestibility comply with the standards of the World Health Organization (WHO) and the Food and Agriculture Organization of the United Nations (FAO) to be used in children with protein deficient diet [16]. The African continent is the most affected 
worldwide in almost its entire extent in terms of malnutrition, and Angola is within the countries with a level between $20-35 \%$ of this condition [17].

In contrast with findings previously presented in studies by Santos, a research by Almeida [18] shows the distribution of moringa across almost the entire length of the African continent. This phenomenon suggests that there has been little research related to this plant and the limited knowledge that is available on the nutritional benefits that moringa offers and could stimulate its cultivation on a larger scale and be part of staple food on the continent. In terms of protein concentration, both offer promising prospects that may justify the interest of making this plant part of a protein food source for both humans and animals, as well as for the reference to its high productivity. The protein contained in this plant has been considered of high biological value due to its essential amino acids content [19]. This plant has become an alternative in the preparation of flour used as food supplement in the fight against malnutrition, mainly in children, the elderly and infants [20].

Another extraordinary finding in the study is related to the great variability in fat content, whose values indicated $5 \%$ in the moringa from Sumbe and $10.54 \%$ in that from Cubal, both representing rich amounts of fat. A study by Marinelli [15] conducted with moringa leaves flour resulted in the obtention of $4.49 \%$ fat content, a low value when compared to this study, while studies by Moyo et al. [21] revealed 6.50\% fat content which is similar to that found in the moringa from Sumbe and lower than that from Cubal. Both Sumbe and Cubal moringa have high ash content, since $11.54 \%$ were found in the sample from Sumbe and 13.8\% from Cubal, what demonstrates the amount of minerals contained in these leaves. These values are higher than that found by Silva, which was $8.0 \%$. The fibre contents obtained in this study were low, with $0.14 \%$ and $0.24 \%$ in the moringa from Cubal and Sumbe, respectively, in comparison to the studies by Moyo et al. [21], which presented a fibre content of $11.4 \%$ in moringa, and Almeida et al. [14], whose findings indicated the existence of $14.4 \%$ crude fibre in this plant, that is considered an excellent source for obtaining this nutrient. With regard to vitamin C, the findings point to $0.22 \%$ in Cubal moringa and $0 \%$ in Sumbe's, whereas data about the moisture content of moringa leaf powder of both locations was similar, having presented values estimated in $5.9 \%$ and $6 \%$, respectively. Almeida et al. [14] found 5.96\% of moisture values, similar to those found in both Sumbe and Cubal moringa. The dry matter was $94 \%$ for both samples. The carbohydrate content in moringa was, respectively, $47.4 \%$ and $52.6 \%$ for Cubal and Sumbe. In comparison, Fink et al. [22] obtained $42 \%$ of carbohydrate content, a result that is similar to that found in this study, what may also mean that it is a source of energy.

\section{Conclusion}

It can be concluded that the moringa from both locations contains a high content of protein, fat and ash, and that the Cubal moringa had less protein content and higher fat and ash content than the moringa of Sumbe.

\section{References}

[1] Gupta, S., Jain, R., Kachhwaha, S., and Kothari, S. L. (2018). Nutritional and medicinal applications of Moringa oleifera Lam.--Review of current status and future possibilities. Journal of Herbal Medicine, 11, 1-11.

[2] Pandey, A., Pandey, R. D., Tripathi, P., Gupta, P. P., Haider, J., Bhatt, S., and Singh, A. V. (2012). Moringa oleifera Lam. Sahijan)_A Plant with a Plethora of Diverse Therapeutic Benefits: An Updated Retrospection. Medicinal and Aromatic Plants, 1(1), 1-8.

[3] Al-Kharusi, L. M., Elmardi, M. O., Ali, A., Al-Said, F. A. J., Abdelbasit, K. M., and AlRawahi, S. (2009). Effect of mineral and organic fertilizers on the chemical characteristics and quality of date fruits. Int. J. Agric. Biol, 11: 290-296.

[4] Anjorin, T. S., Ikokoh, P., and Okolo, S. (2010). Mineral composition of Moringa oleifera leaves, pods and seeds from two regions in Abuja, Nigeria. Int. J. Agric. Biol, 12(3): 431-434.

[5] Gopalakrishnan, l., Doriya, K., Kumar, D. S. (2016). Moringa oleifera: A review on nutritive importance and its medicinal application. Food Science and Human Wellness, 5(2): 49-56.

[6] Oyeyinka, A. T. and Oyeyinka, S. S. (2016). Moringa oleifera as a food fortificant: Recent trends and prospects. Journal of the Saudi Society of Agricultural Sciences, 17(2): 127-136.

[7] Martínez-González, C. L., Martínez, L., Martínez-Ortiz, E. J., González-Trujano, M. E., Déciga-Campos, M., Ventura-Martínez, R., and Díaz-Reval, I. (2017). Moringa oleífera, a species with potential analgesic and anti-inflammatory activities. Biomedicine \& Pharmacotherapy, 87: 482-488.

[8] Wang, Y. Gao, Y., Ding, H., Liu, S. Han, X., Gui, J., and Liu, D. (2017). Subcritical ethanol extraction of flavonoids from Moringa oleifera leaf and evaluation of antioxidant activity. Food Chemistry, 218: 152-158.

[9] Metwally, F. M., Rashad, H. M., Ahmed, H. H., Mahmoud, A. A., Raouf, E. R. A., and Abdalla, A. M. (2017). Molecular mechanisms of the anti-obesity potential effect in the experimental model. Asian Pacific Journal of Tropical Biomedicine, 7(3): 214-221. 
[10] Muhammad, H. I., Asmawi, M. Z., and Khan, N. A. K. A. (2016). A review on promising phytochemical, nutritional and glycemic control studies on Moringa oleifera Lam. in tropical and sub-tropical regions. Asian Pacific Journal of Tropical Medicine, 6(10): 896-902.

[11] Cunha, A. P., Silva, A. P., Roque, O. R. (2006). Plants and vegetables products in fitotherapy. Colouste Gulbenkian Foundation. Education and Scholarships Service. Lisbon - Portugal (2ed): 21-54. Ethnopharmacology, 66, 33-39.

[12] Zatta, M. (2007). Nature’s Farmacy 20a ed. Sant Paulo: Paulinas. P. 141.

[13] Geron, L. J. V., Cabral, L. S., Trautmann-Machado, R. J., et al. (2014). Evaluation of neutral and acid detergent using different procedures applied to forrage plants. Agrarian Sciences, Londrina, 35(3): 1533-1542.

[14] Almeida, M. E. F., Junqueira, A. M. B., Simão, A. A., Corrêa, A. D. (2014). Chamical Characterization of Unconventional Vegetables Known as Ora-ProNobis. Rev. Biosci. J., Uberlândia, 30(1): 431-439.

[15] Marinelli, P. S. (2016). Moringa flour (Moringa Oleifera Lam.) and Ora-pro-nóbis (Pereskia aculeata Mill.): funtional biomaterials. Sheet.59. Doctorate Thesis, Estadual Paulista University. Faculty of Sciences, Bauru.

[16] Sohaimy, S. A., Hamad, G. M., Mohamed, S. E., Amar, M. H., Al-Hindi, R. R. (2015). Biochemical and functional properties of Moringa oleifera leaves and their potential as a functional food. Global Advanced Research. Journal of Agricultural Science, 4(4): 188-199.

[17] Santos, A. F. S., Luz, L. A., Pontual, E. V., Napoleão, T. H., Paiva, P. M. G., Coelho, L. C. B. B. (2015). Moringa oleifera: Resource Management and Multiuse Life Tree. Advances in Research, 4(6): 388-402.

[18] Almeida, M. S. M. (2018). Moringa oleifera Lam., its medicinal and nutritional benefits and toxicity avaliation. Master's Dissertation, Faculty of Farmacy, University of Coimbra, Portugal.

[19] World Health Organization. (1985). Energy and protein requirements. Report of a Join FAO/WHO/UNU Expert Consultation Meeting Series, n.724, Geneva, Switzerland.

[20] Teixeira, E. M. B. (2012). Chemical and nutritional characterization química of moringa leaf (Moringa oleífera Lam.) sheet. 94. Doctorate Thesis. Araraquara, São Paulo.

[21] Moyo, B., Masika, P. J.. Hugo, A., Muchenje, V. (2011). Nutritional characterization of Moringa (Moringa oleifera Lam.) leaves. African Journal of Biotechnology, Kenya, 10(60): 12925-12933.

[22] Fink, S. R., Konzen, R. E., Vieira, S. E., Ordonez, A. M., Nascimento, C. R. B. (2018). Benefits of non-conventional food plants PANCs: Caruru (Amaranthus Viridis), Moringa Oleífera Lam. and Ora-pro-nóbis (Pereskia Aculeata Mill) Pleiade, 12(S1): 39-44. 